Bangladesh J. Zool. 41(2): 189-198, 2013

\title{
ACTIVITY PATTERN OF WHITE-BREASTED WATERHEN (AMAURORNIS PHOENICURUS) AT JAHANGIRNAGAR UNIVERSITY CAMPUS, SAVAR, DHAKA, BANGLADESH
}

\author{
Sharmin Akhtar, M.M. Kabir, Sajeda Begum and M.K. Hasan \\ Department of Zoology, Jahangirnagar University, \\ Savar, Dhaka, Bangladesh
}

\begin{abstract}
Activity pattern of white-breasted waterhen (Amaurornis phoenicurus) was studied during May 2007 to April 2008 at Jahangirnagar University Campus, Savar, Dhaka, Bangladesh. They spent most of the daily time (35.46\%) for foraging and feeding. Hiding was the second highest activity (26.75\%) while moving, preening, calling, resting activities and changing other wetland birds constituted $11.33 \%, 8.59 \%, 6.13 \%, 5.20 \%$ and $5.12 \%$, respectively. Breeding season lasted from February to July with the breeding activities found in April $(9.41 \%)$. The white-breasted waterhens avoided the conflict with other wetland birds by hiding themselves.
\end{abstract}

Key words: White-breasted Waterhen, Activity pattern, Foraging and feeding.

\section{INTRODUCTION}

Wetland birds are the most attractive birds and found in freshwater marshes, estuaries and as well as in marine habitat. Most of the wetland birds in the world are under threat and they are the vital indicator of environmental health (Hayman et al. 1995). Wetlands in Bangladesh, as elsewhere, are facing tremendous anthropogenic pressures, which can greatly influence the status and distribution of bird community. Wetland birds have attracted the attention of the general people and researchers because of their aesthetic value, abundance, visibility and social behavior, as well as for their recreational and economic importance. Recently, wetland birds have become the target of interest as indicators of wetland quality and as parameters of restoration success and regional biodiversity (Kumar and Gupta, 2009).

In Bangladesh a total 50 species of resident wetland birds are found, of which 9 species are threatened in different categories (IUCN, 2000). Different species of herons (Ardeola grayii, Butorides striatus) and egrets (Egretta garzetta, Bubulcus ibis, Casmerodius albus), cormorants (Phalacrocorax spp.), bronzewinged jacana (Metopidius indicus), white-breasted waterhen (Amaurornis phoenicurus), whistling ducks (Dendrocygna spp.) and so on are common wetland birds in lakes and ponds in Bangladesh. Jahangirnagar University (JU) Campus is widely known for its diverse habitats including wetlands those provide breeding and feeding habitats for many resident and migratory birds (Feeroz et al. 1988, Joarder 1997, Begum 2000, Akhtar et al. 2009). The 
university campus is the suitable habitat of 180 species of birds including 33 species of waders (Mohsanin and Khan 2009).

White-breasted waterhen is a common resident wetland bird in Jahangirnagar University campus and it is well distributed in the lakes of the campus. Several studies on pond heron, bronze-winged Jacana, red wattled lapwing and other birds are available (Begum 2000, 2001, 2002, 2003; Joarder 1997, Sultana et al. 2004, Islam 1995, Akhtar et al. 2007, 2009). Previous studies on white breasted waterhen are limited to little information on its food habits and habitats, but detailed study on the activity patterns of white-breasted waterhen in its different habitats is still lacking. The main objective of the present study was to find out different behavioural activities of the whitebreasted waterhen to suggest management plans to conserve this bird as well as its habitat.

\section{MATERIAL AND METHODS}

The study was conducted in a lake of Jahangirnagar University Campus, Savar, Dhaka during May 2007 to April 2008. A total of 48 days (309 hours) were spent in the field and recorded a total of 4357 scans consisting of 7532 observations during the study period. All the visible individuals in the habitat were counted by direct encounter method. The activity patterns of this species were recorded by using scan sampling method (record each animal's behavior at predetermined time for certain period) with 5 minutes intervals (Feeroz and Islam 1992, Hasan et al. 2005, Akhtar et al. 2007, 2009, Martin and Bateson 1993). The activities of all the visible individuals were recorded in each scan. The behaviour of one individual during the scan was recorded as one observation. Other important behaviours (event or instantaneous behaviour e.g. courtship and copulation, mating etc.) were also noted as ad libitum note in between scans. Significance of different activity patterns in different months and hours were assessed with a Chi-Square test (Grassman et al. 2005 and McCoy 1986). Activities were recorded as foraging and feeding, moving, resting, calling, preening, chasing, hiding and breeding (Akhtar et al. 2009).

Foraging and feeding: when an individual actively searched for food or successfully captured and swallowed any food item then the observation was recorded as foraging and feeding. Sometimes the birds were seen to feed and wade simultaneously, and then it was recorded as feeding not wading.

Moving: it includes directed or non-directed movement from one place to another. When an individual moved from one place to other rather than foraging or feeding then it was recorded as movement. 
Resting: when an individual became inactive, standing or sitting motionlessly, was recorded as resting but when resting and preening occurred simultaneously then it was recorded as preening not resting.

Calling: when an individual actively created sound or play song; but when calling and other activity such as foraging, flying, resting etc. was occurred simultaneously then it was recorded as calling activity not others.

Preening: when an individual was cleaning and rearranging feathers with the bill then it was recorded as preening.

Chasing: when an individual actively defended any individual of the same species or different species was recorded as chasing.

Hiding: if an individual took shelter inside bushes, grasses or any types of vegetation when alarmed by any intruder was recorded as hiding.

Breeding: when a male or female performed any breeding activities. Breeding activity was further categorized as pair formation, courtship, nesting site selection, nest building, incubation and rearing.

\section{RESULTS AND DISCUSSION}

Overall activity budget: The activity budget is defined as the proportion of time an animal spent in different activities that are important for its survival and reproduction (Dunbar and Dunbar, 1974). Activity patterns of whitebreasted waterhen varied with the daytime and availability of food in their habitat. Overall time spent for different activities in each hour of the day varied significantly $\left(\chi^{2}=687.178, \mathrm{df}=91, \mathrm{P}<0.001\right)$. White-breasted waterhen spent the highest amount of their daytime in foraging and feeding (35.46\%) and less time in chasing (3.12\%). Hiding was the second highest activity $(26.75 \%)$. They spent $11.33 \%$ time in moving, $8.59 \%$ in preening, $6.13 \%$ in calling, $5.20 \%$ in resting and $3.42 \%$ time in breeding activities respectively (Fig. 1). Overall activity budget of white-breasted waterhen in different months was also varied significantly $\left(\chi^{2}\right.$ $=603.94, \mathrm{df}=77, \mathrm{P}<0.001$ ).

\section{Monthly and daily activity pattern}

Foraging and feeding: Maximum foraging and feeding activity was recorded in August (39.81\%) during monsoon just after the breeding season. Excessive growth of plants like Salvinia sp., Eichhornia sp., Nymphaea sp. was noted during monsoon. Such flooded lakes attracted deep water birds and many waders for their availability of prey items and they were also adapted to walk over floating plants and to feed on from those. Ramachandran and Vijayan (1995) reported that Jacanas feed on aquatic macrophytes and macro invertebrates associated with the plants. Several species of fish, aquatic insects 


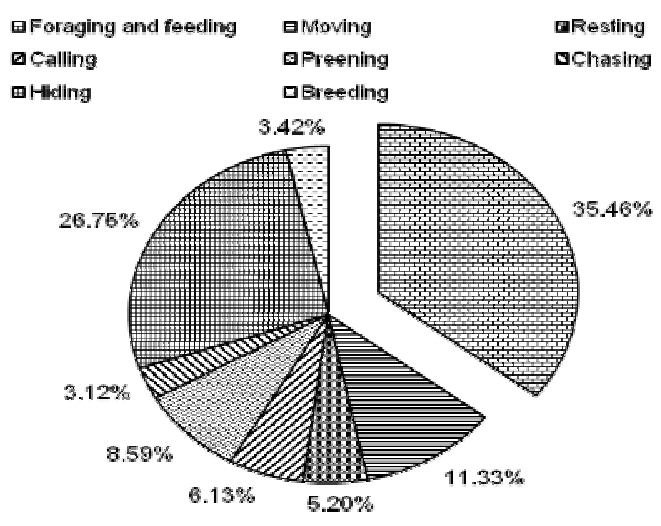

Fig. 1 Overall activity budget of white-breasted waterhen

and occasionally amphibian (frogs and tadpoles of Rana spp.) are available in the lakes during monsoon which facilitate waterhen and its growing nestlings to spend most of the time in foraging and feeding. The breeding pair mostly active in breeding activities and hence minimum foraging and feeding was in April (31.87\%) (Fig. 2). White-breasted waterhen foraged and fed most actively before noon with the peak at $0700 \mathrm{~h}(12.17 \%)$. After overnight fasting they try to maximize foraging and feeding during early morning. Similar observation was found in Bronze-winged Jacana (Akhtar et al. 2009). This tendency was more common during the winter season (October to January); because of relatively shorter day length as well as longer length of night. Foraging and feeding techniques of white-breasted waterhen depend on location of feeding habitat and the size, type of the diet. They mainly used three types of foraging and feeding techniques to collect their foods: (i) foraging and feeding with walking which was mostly used $(83 \%)$ by waterhen to find out insects effectively as waterhen is chiefly insectivore, (ii) foraging and feeding with wading which was very rare (3.97\%) because they occasionally consume mollusks and small fishes, and (iii) foraging and feeding with running (13.03\%) (Fig. 4). Foraging, feeding and diet of birds reflect with the bill shape and size and it has been clearly demonstrated in the studies of finches (Kear 1962, Grant 1986, Smith 1987), ducks and many other birds (Kehoe and Thomas 1987). The bill of white-breasted waterhen is moderate, stout but suitable for insect capturing. As they spent a significant amount of their active time in hiding, they require energy rich food within short time and protein rich insect foods that provide rapid energy. 


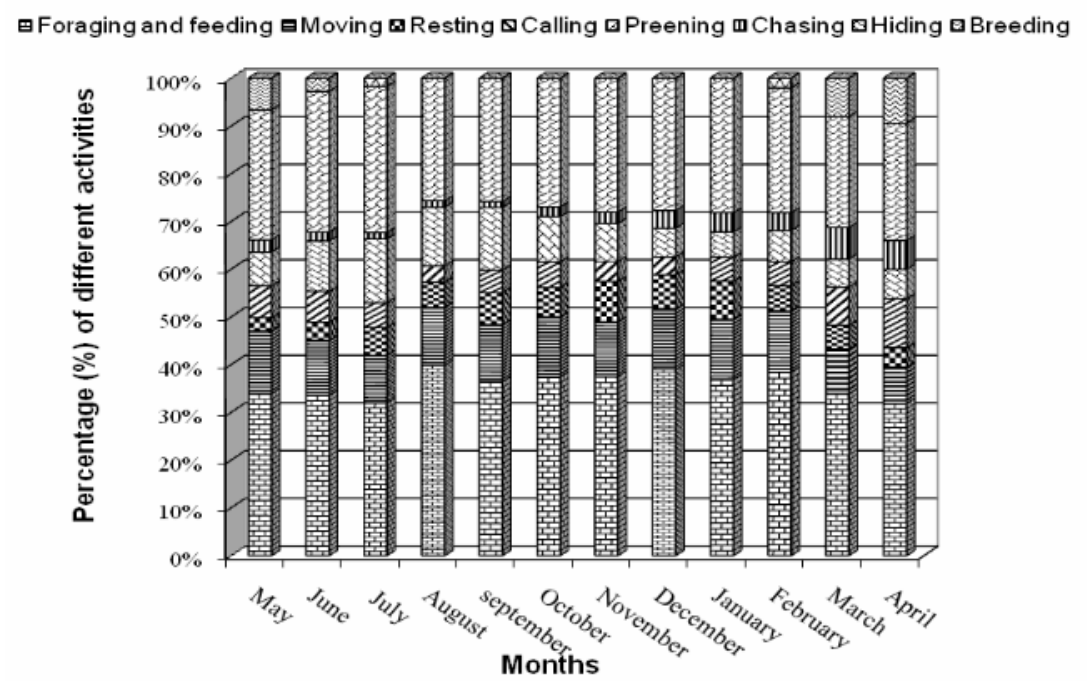

Fig. 2 Monthly variations in different activities of white-breasted waterhen

Moving: Moving was the maximum in May (13.15\%) (Fig. 2). Moving increased just after hatching of the young while following the parents and it was the minimum in April (7.59\%) while incubation continuing. They moved and climbed about in the dense crown-foliage of waterside bushes and small trees (Wells 1999). The peak of moving was at $0800 \mathrm{~h}$ (11.25\%). After the feeding peak in a place they usually change feeding place to search more foods which increases their movement. Moving peak at next hour of foraging and feeding peak could be the reason for this. Moving of white-breasted waterhen was recorded under four categories: walking, running, wading and flying. They spent the highest time in walking (38.10\%) followed by running $(17.94 \%)$, wading $(31.07 \%)$ and flying $(12.90 \%)$. Overall moving activity in different categories varied significantly $\left(\chi^{2}=138.1325, \mathrm{df}=3, \mathrm{P}<0.001\right)$.

Resting: They remained less active $(8.48 \%)$ in November and the reason my be that the wetlands are used as feeding ground of large number of different species of migratory ducks. They took little rest in May (2.76\%) (Fig. 2). The resting peak was at $1400 \mathrm{~h}(14.03 \%)$ and the minimum $(2.04 \%)$ at $1900 \mathrm{~h}$ (Fig. 3). On the mid-day to avoid hot weather especially during summer white-breasted waterhen take rest. Similar finding was found in Bronze-winged jacana (Akhtar et al. 2009). Diurnal variations in resting varied significantly $\left(\chi^{2}=132\right.$, df $=13$, $\mathrm{P}<0.001)$. Resting of white-breasted waterhen was positively correlated with preening $(\mathrm{r}=0.64, \mathrm{~N}=12)$. 
Calling: For calling, they spent the maximum time in April (10.24\%) which was related mostly to breeding activities and it was the minimum in August (3.40\%) (Fig. 2). The maximum (11.90\%) calling was observed at $0700 \mathrm{~h}$ and the minimum $(3.68 \%)$ was at 1500 h (Fig. 3). During early morning they actively search their suitable feeding place that's why they give call to communicate with other individual. Diurnal variations in calling varied significantly $\left(\chi^{2}=57.21\right.$, $\mathrm{df}=13, \mathrm{P}<0.001)$.

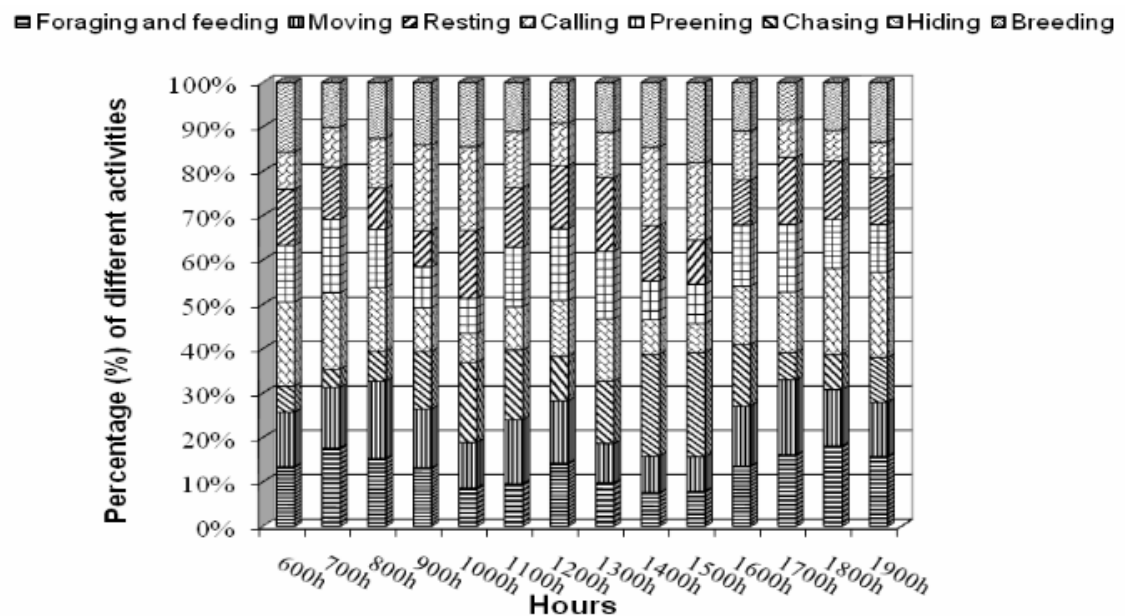

Fig. 3 Diurnal variations in different activities of white-breasted waterhen

Vocalization or call is important for attracting males and detecting territory. White-breasted waterhen is non-territorial but uttered loud calls during the periods of its courtship display, incubation and caring for young. Calling activity of this species also increased with the breeding season thus the maximum calling activity was observed in April (10.24\%). Calling was loud and prolonged indicating probable breeding (Feijen and Feijen 2008). Breeding activity was marked by vigorous calling mostly in the morning which leads to pair formation (Gopakumar and Kaimal 2007).

Preening: Preening activity was the maximum in July $(13.40 \%)$ after the breeding season, while it was the minimum in January (5.24 \%) (Fig. 2). The maximum preening (11.59\%) was observed at $1200 \mathrm{~h}$ and the minimum $(2.16 \%)$ was at $1900 \mathrm{~h}$ (Fig. 3). Preening usually found to increase after swimming. Diurnal variations in preening varied significantly $\left(\chi^{2}=95, \mathrm{df}=13, \mathrm{P}<0.001\right)$.

Preening is one of the important body-maintenance activities of birds. Bathing and preening, scratching with the claws, help allay itching, remove ecto-parasites, and clean the feathers. Preening with oil from the uropygial gland (preen gland) helps them to maintain their feather very well (Welty and Baptista 
1988). Preening was the third highest activity (8.59\%) of white-breasted waterhen. In the month of the highest rainfall in July $(700.0 \mathrm{~mm})$, the highest preening was recorded, as they need to preen their feather after a heavy shower; the females of white-breasted waterhen were found to preen after copulation to rearrange their feather. Similar finding was observed in bronze-winged Jacana (Joarder 1997, Akhtar et al. 2009).

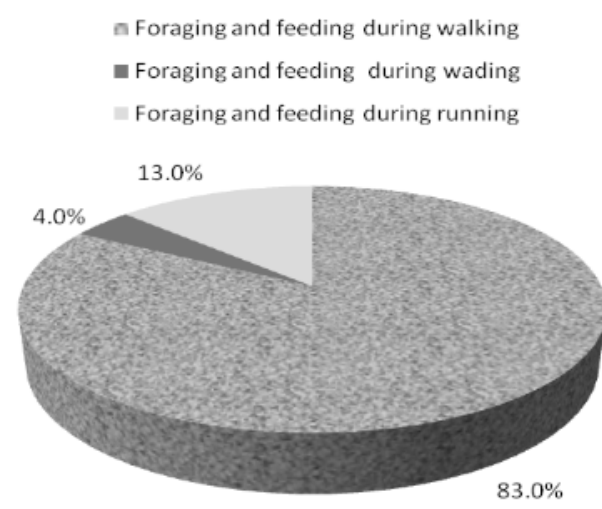

Fig. 4 Proportion of different foraging and feeding techniques of white-breasted waterhen

Chasing: The highest time spent in chasing was found in March (6.70\%) during breeding season. They became aggressive after the start of laying eggs. Crows, treepies approaching the nest were found chased away by the waterhen (Kumar and Gupta, 2009). Chasing was lowest in September (1.25\%) (Fig. 2). The maximum chasing (11.49\%) was recorded at $1200 \mathrm{~h}$ and the minimum $(2.13 \%$ ) was at $1900 \mathrm{~h}$ (Fig. 3). Chasing peak was at noon during other sympatric birds were active in the same ground. Diurnal variations in chasing varied significantly $\left(\chi^{2}=31.6, \mathrm{df}=13, \mathrm{P}<0.01\right)$. Chasing was positively correlated with calling $(\mathrm{r}=0.94, \mathrm{~N}=12)$. During courtship male of white-breasted waterhen usually chase female. Chasing also related with the presence of other sympatric birds in the same ground.

White-breasted waterhen is a shy and peaceful bird thus they spent less time in chasing $(3.12 \%)$ compare to other activities. In non breeding season they shared the same foraging and feeding ground with other wetland birds. Both the male and female chased any intruders with loud calling during incubation.

Hiding: The maximum time spent in hiding were observed in July (30.58\%) to avoid conflict with other wetland birds, namely cormorants, jacanas, moorhen and it was minimum in March (23.21\%) during breeding season. The maximum hiding $(13.60 \%)$ was recorded at $1000 \mathrm{~h}$ and the minimum $(1.64 \%)$ was at $1900 \mathrm{~h}$ (Fig. 3). Hiding in different hours of the day varied significantly $\left(\chi^{2}=460.46\right.$, df 
$=13, \mathrm{P}<0.001)$. Hiding was observed to increase after the first bout of feeding during $900 \mathrm{~h}-1000 \mathrm{~h}$ and decreased with the increase of foraging and feeding activity during morning and afternoon. White-breasted waterhen avoided any conflicts with other wetland birds by hiding themselves.

Breeding: The maximum breeding activities were found in April (9.41\%) and the lowest in July (1.72\%) (Fig. 2). No breeding activities were found in August, September, October, November, December and January (Fig. 2). Overall breeding activities were varied significantly in different months $\left(\chi^{2}=812.87\right.$, df $=11, \mathrm{P}<0.001)$. The maximum breeding activities were observed at $1000 \mathrm{~h}$ $(10.51 \%)$ while the least were at $1900 \mathrm{~h}(2.72 \%)$ (Fig. 3). After first bout of feeding, they were found to use their energy in breeding activities. Breeding activities in different hours of the day also varied significantly $\left(\chi^{2}=27.74, \mathrm{df}=13\right.$, $\mathrm{P}<0.02)$. Breeding activities were positively correlated with calling $(\mathrm{r}=0.96, \mathrm{~N}$ $=12$ ).

They spent the maximum breeding time in incubation $(41.63 \%)$ followed by nest building (32.30\%), rearing the chicks (14.01\%) and courtship and copulation (12.06\%).

Breeding activities of white-breasted waterhen lasted from April to June (Sultana 2002). It extended from April through September (Sharma and Singh 2013). Ali and Ripley (1987) mentioned that the breeding season mainly coincide with the south-west monsoon in June-July to October. The present findings partially supported the findings of Sultana (2002) but differed with Ali and Ripley (1987). The reason may be that monsoon started earlier in our country.

The findings of the present study showed that white-breasted waterhen spent different proportion of time in different activities. Activity patterns significantly varied in different hours of the day as well as in different months which help them to avoid inter specific conflicts with other wetland birds in the same feeding and breeding grounds. These findings will play an important role for the management and conservation of this bird as well as other sympatric wetland birds.

\section{LITERATURES CITED}

AKHTAR, S., KABIR, M.M., HASAN, M.K. and BEGUM, S. 2007. Activity pattern of Pied kingfisher (Ceryle rudis) at Jahangirnagar University Campus. Bangladesh J. Life Sci. 19(1): 49-58.

AKHTAR, S., KABIR, M.M., HASAN, M.K. and BEGUM, S. 2009. Activity pattern of Bronze-winged Jacana (Metopidius indicus) at Jahangirnagar University Campus. Bangladesh J. Life Sci. 21(2): 111-120.

ALI, S. and RIPLEY, S.D. 1987. Compact handbook of the birds of India and Pakistan together with those of Bangladesh, Nepal, Bhutan and Srilanka. $2^{\text {nd }}$ edition, Oxford University Press, Delhi. 
BEGUM, S. 2000. Feeding and breeding behaviour of pond heron (Ardeola grayii garyii) in Bangladesh. M. Phil. Thesis (Unpublished). University of Cambridge.

BEGUM, S. 2001. Pair-formation displays of the pond heron (Ardeola grayii grayii). J. Asiat. Soc. Bangladesh, Sci. 27(1): 59-66.

BEGUM, S. 2002. Food and feeding behaviour of pond heron (Ardeola grayii grayii) of Bangladesh. Bangladesh J. Life Sci. 14(1\&2): 87-93.

BEGUM, S. 2003. Colonial nesting behaviour in Indian Pond Heron (Ardeola grayii grayii) of Bangladesh. Zoos' Print Journal 18(6): 1113-1116.

DUNBAR, R.I.M. and DUNBAR, E.P 1974. Ecology and population dynamics of Colobus guereza in Ethiopia. Folia Primatologica. 21: 188-208. Edinburgh, London.

FEEROZ, M.M., ZAVED, A.A. and ISLAM, M.A. 1988. A checklist of Medicinal plants, Fresh water organisms and vertebrate fauna of the J. U. Campus. Bangladesh J. Life Sci. 1(1): 65-85.

FEEROZ, M.M. and ISLAM, M.A. 1992. Ecology and behaviour of hoolock gibbons of Bangladesh. MARC (Multidisciplinary Action Research centre), Dhaka, Bangladesh.

FEIJEN, C. and FEIJEN, H.R. 2008. A review of the breeding birds of Bhutan. Forktail, 24: 1-24.

GOPAKUMAR, P.S. and KAIMAL, P.P. 2007. Loss of Wetland Breeding Habitats and Population Decline of White Breasted Water Hen, Amaurornis Phoenicurus Phoenicurus (Pennant)-A Case Study. In Proceedings of Taal 2007: The 12th World Lake Conference (Vol. 529, p. 536).

GRANT, P.R. 1986. Ecology and evolution of Darwin's finches. Princeton: Princeton University Press.

GRASSMAN, L.I., JR., TEWES, M.E. and SILVY, N.J. 2005. Ranging, habitat use and activity patterns of binturong Arctictis binturong and yellow-throated marten Martes flavigula in northcentral Thailand. Wildl. Biol. 11(1): 49-57.

HASAN, M.K., FEEROZ, M.M., ISLAM, M.A., KABIR, M.M., BEGUM, S., AZIZ, M.A. and SARKER, G.C. 2005. Food and feeding behaviour of hoolock gibbon (Bunopithecus hoolock hoolock) in a semievergreen forest of Bangladesh. Bangladesh J. Life Sci. 17(1): 43-49

HAYMAN, P., MARCHANT, J. and PRATER, T. 1995. Shore birds: an identification guide. J. for Ornith. 70: 172-285.

ISLAM, M.A. 1995. Breeding behaviour of White-breasted laughing thrush Garrrulax jerdoni Blyth (Aves: Muscicapidae). Bangladesh J. Zoology. 23(2): 125-132.

IUCN, 2000. Red Book of Threatened Birds of Bangladesh. IUCN Bangladesh.

JOARDER, N. 1997. Ecology and behaviour of Bronze-winged jacana in Jahangirnagar University, Savar, Dhaka. M. Sc. Thesis (Unpublished).

KEAR, J. 1962. Food selection in finches with special reference to interspecific differences. Proc. Zool. Soc. London. 138: 163-204.

KEHOE, F.P. and THOMAS, V.G. 1987. A comparison of interspecific differences in the morphology of external and internal feeding apparatus among North American Anatidae. Canadian Journal of Zoology. 65: 1818-1822.

KUMAR, P. and GUPTA, S.K. 2009. Diversity and Abundance of Wetland Birds around Kurukshetra, India. Our nature 7(1): 212-217.

MARTIN, P. and BATESON, P. 1993. MEASURING BEHAVIOUR: An Introductory guide. $2^{\text {nd }}$ edn., Cambridge University Press.

McCOY, M. 1986. Movements, habitat use and activity patterns of a translocated group of Roosevelt Elk. M. Sc. Thesis. The Faculty of Humboldt State University. 
MOHSANIN, S. and KHAN, M.M.H. 2009. Status and seasonal occurrence of the birds in Jahangirnagar University Campus, Bangladesh. Bangladesh J. Life Sci. 21(1): 29-37.

RAMACHANDRAN, N.K. and VIJAYAN, V.S. 1995. Breeding ecology of the Bronze-winged (Metopidius indicus) and Pheasant-tailed (Hydrophasianus chirurgus) jacanas in Keoladeo National Park, Bharatpur, Rajasthan. J. Bombay nat. Hist. Soc. 92(3): 322-334.

SHARMA, K.K. and SINGH, P. 2013. Dynamics of migratory waterfowl abundance at lake Mansar (Ramsar site): A transient and wintering site. International J. Current Life Sci. 3(2): 9-13.

SMITH, T.B. 1987. Bill size polymorphism and intraspecific niche utilization in an African finch. Nature, London. 329: 717-719.

SULTANA, S. 2002. Feeding and breeding behaviour of three wetland birds of Jahangirnagar University campus, M.Sc. dissertation (unpublished), Department of Zoology, Jahangirnagar University.

SUlTANA, S., BEGUM, S. and FEEROZ, M.M. 2004. Comparative study on breeding activities of three wetland birds in Bangladesh. Bangladesh J. Life Sci.16(2): 67-73.

WELLS, D.R. 1999. The birds of the Thai-Malay Peninsular. Vol. I, Non-passerines. Academic Press, London. 648 pp.

WELTY, J.C. and BAPTISTA, L. 1988. The life of birds. Saunders College Publishing, New York. 